\title{
Influence of Adherence to Leave Policies on Teachers' Performance in Public Secondary Schools in Homa-Bay County
}

\author{
${ }^{1}$ Jane Akinyi Joseph*, ${ }^{2}$ Matula Phylisters and ${ }^{3}$ Okoth Ursulla \\ ${ }^{1,2,3}$ Department of Educational Administration and Planning University of Nairobi, P. O. Box 30197 - \\ 00100, Nairobi, Kenya
}

\begin{abstract}
The provision of paid leave and time-offs are practices in human resource administration that aims at reducing burnout, stress as well as family-work conflict. Thus, provision of leave allows an employee to recuperate from the daily pressure of work. However, in the education sector in Kenya, information concerning administration of leave policies to teachers is not clear. In some counties such as Homa Bay in Kenya, secondary school teachers are faced with problems such lesson overload, inadequate time-offs for sick and lactating teachers, and inadequate bereavement leaves. The number of teachers seeking for transfer has also increased over the years. The purpose of this study was to analyse the influence of adherence to leave policies by school administration on performance of teachers in public secondary schools in Homa Bay County. Specific objectives were to determine the level of teachers' performance and to establish the influence of provision of leave on performance of teachers. The study employed descriptive survey design. Target population comprised a total of 257 principals and 2,231 teachers. Yamane's formula was used to calculate 292 teachers and 22 Principals from whom data was collected using questionnaire and interview schedule respectively. The study found that adherence to leave policies $(\mathrm{F}=66.488 ; \mathrm{P}$ $=0.0)$ as a significant predictor of teachers' performance abeit with a low contribution $\left(21.8 \%\right.$ or $\left.\mathrm{R}^{2}=0.218\right)$ change in teacher performance. It is concluded that adherence to leave policies do not provide adequate satisfaction to elicit effort towards enhanced performance among secondary school teacher.
\end{abstract}

Key words: Family Leave; Leave policies; Maternity/paternity Leave; Teacher Performance; Public Secondary schools;

\subsection{Introduction}

Employees are increasingly subjected greater job demand and are called upon to be available to work all hours a day and nearly all days a week for the purposes of enhacing performance (Ostoj, 2019). Similarly, more female employees are currently joining the labor force (Al Kabir \& Tirno, 2018). Balancing between taking care of the family and undertaking work duties therefore becomes a source of conflict many families in the contemporary institutional management continuum (Nwagbara, 2020). This notion is central to achieving sustainable development goals (SDGs) globally, in particular, goal 3, which is about good health and wellbeing (KPMG, 2017). It also resonates with the United Nations' (UN, 2015) call for a world with greater survival prospects for mothers and equal opportunities for women. According to Hammer and Palmgren (2019), provision of employee leave forms a critical approach that reduces conflicts between work and social roles. Ostoj (2019) explains that a leave policy sets out the various types of leaves for different situations like a vacation, sickness, maternity, and grief among others. Indeed researchers (Ryder, 2014; Mohamud, 2016; Al Kabir \& Tirno, 2018) have documented that provision of leave to workers is critical in easing burnout and enhancing employee satisfaction. However, applications and adherence to various forms of leave to employees tend to vary across the globe, same way with their effectiveness.

The Organization of European Union (OED, 2017) state that employees have the right to varying forms of paid leave which go for diverse periods and payments between the European countries. In the Netherlands, Begall, van Breeschoten, van der Lippe \& Poortman (2020 revealed that perceived availability of supplemental family leave relates positively to employees' contextual performance, partially by increasing organizational commitment. 
Choudhury and Polachek (2019) found evidence that paid family leave policy had a stronger impact on families that are below the poverty line in Carlifonia. Garg and Agrawal (2020), on their part showed that family-friendly practices in organizations have focused mainly on topics such as availability and usability of family-friendly policy, job satisfaction, and organizational performance among others. On the other hand, Mhando \& Kayuni (2019) revealed in a study done in Tanzania that working mothers face individual, societal, and organizational challenges at work. In Kenya, Muasya (2016) found that lactating teachers ask for permission/assistance from supervisor/colleagues to attend to family emergencies since there were no formal policy arrangement for breast feeding. It is therefore critical to enquire how provision of different types of leave has elicited performance of teachers especially in secondary schools seems to have received limited documentation.

The critical role of teachers in the provision of quality education world over cannot be negated. The Dakar Framework for Action of 2000 (UNICEF, 2017) as well as the Incheon Declaration at the World Education Forum (WEF, 2015) articulated the importance of ensuring that teachers and educators are well motivated and supported within wellresourced, efficient and effectively governed systems. The Sustainable Development Goal number 4 (SDG 4) of attaining inclusive and equitable quality education and promote lifelong learning opportunities for all by 2030 (ILO, 2018 ) is critically dependent upon effective teaching. It is thus imperative to design and implement strategies of ensuring that teachers become comfortable at their workplaces. This is because satisfied employees can more effectively fulfill their duties to facilitate achievement of organizational goals (Uzun and Özdem, 2017). According to Koutouzis and Malliara (2017) teachers' job satisfaction is a factor which significantly affects many aspects of quality in education. ILO (2018) specifically implicated the necessity of leave provision as a panacea for burnout and general employee disatisfaction: critical factors that often impede performance of teachers. It was therefore imperative to explore how adherence to leave policies by the school administration has influenced performance of teachers. This was critical especially in areas such as Homa Bay County in Kenya with numerous cases of teacher turnover and of identifies trained, experienced and motivated teachers amongst other factors, as critical resource for quality education

Homa Bay County has in the recent period witnessed numerous incidents of absenteeism and lateness to school in disregard to official reporting time. This has been rampant especially with young female teachers who are often off school attending to family issues. This is a critical indicator to work life conflict. There is also high rates of teacher turnover, especially victims of suspensions for absenteeism without permission. On their turn, most young teachers face stress related to work overload, student indiscipline. As a result most teachers lack motivation to work hard. The Kenya Government has put in place policies to address issues that might cause serious work-family conflict such as various leave options including maternity/paternity leave, comapassionate leave, and sick leave among others. In addition, individual learning institutions have often availed bereavement leave and funds in cases of grief to insulate teachers from misfortunes associated with such circumstances. However, despite the measures and interventions by the government and individual schools to address the problem of work life balance among the teacher in Homa Bay County, teachers still experience conflict as regard the teaching job and the individual life as they continue to look for the kind of life they desire.

\section{Purpose of the Study}

The purpose of the study was to explore how adherence to leave policies influence performance of teachers in public secondary schools in Homa Bay County, Kenya.

\section{Specific Objectives}

Specific objectives were to:

i. Determine the level of performance of teachers among public secondary schools in Homa Bay County, Kenya

ii. Determine how maternity/paternity leave uptake influence performance of teachers in public secondary schools in Homa Bay County, Kenya.

\section{Literature Review}

Hammer and Palmgren (2019) explored how parental leave influence employee engagement, and subsequent employee retention. Empirical data was collected through 18 semi-structured interviews with employees in Sweden and the United States. Parental leave was found to influence employee engagement and retention in four main ways (themes), which are relationship with manager, salary and career opportunities, alignment of values, and well-being. In Australia, Hendrawijaya et al (2020) analyzed the effects of performance allowance, work discipline, work culture, and leadership on teacher performance viewed from direct effect and indirect effect with job satisfaction as the mediation. The study showed that performance allowance, work discipline, work culture, and leadership directly affected job satisfaction and also teacher performance. In Sweden, Ostoj (2019) examined the differences in the length 
of paid annual leave between countries and regions in average terms and depending on tenure, as well as to identify the groups of countries and regions where paid annual leave is relatively longest and shortest. Findings showed that the length of paid annual leave depends on systemic, in particular cultural, factors.

In Netherlands, Begall, et al (2020) investigated whether the provision of supplemental family leave elicits higher work effort and extra-role behavior in employees. Their results indicated that perceived availability of supplemental family leave relates positively to employees' contextual performance, partially by increasing organizational commitment. This effect is found irrespective of actual use of family leave and is not moderated by characteristics relating to future use such as having young children, being of childbearing age or being female. Wilson, Punjani, Song and Low (2019), on their part, sought an understanding of bereavement grief leave on the workplace employees in Canada. Findings showed that two of every three organizations had 10 employees took a bereavement leave in the previous last year, with $3.2 \%$ of all employees taking a bereavement leave consisting of 2.5 days on average and often with additional travel and accommodation days. Similarly, Choudhury and Polachek (2019) analyzed the impact of time constraints on immunization of infants on time. To establish a causal relationship, we exploit California's implementation of Paid Parental Leave Program as a natural experiment. They found evidence that the policy reduced late vaccinations for children born to parents in California after the policy was implemented. They also found that the policy had a stronger impact on families that are below the poverty line.

In another study, In India, Garg and Agrawal (2020) sought to identify the emerging trends in the area of "family friendly practices" by carrying out an exhaustive literature review. The study synthesized the literature between the years 2010 and 2019. The findings showed that family-friendly practices has focused mainly on seven topics: availability and usability of family-friendly policy, job satisfaction, organizational performance, supervisor or manager support, work-life conflict, employee turnover employee retention and women's employment. Regionally, Fapohunda (2014) analysed the influence of work life balance (WLB) on employee productivity and how Nigerian workers handle the inauspicious working situations and coordinate their work and family lives. The author also explored the connection between work life balance (WLB) practices and organizational productivity and whether WLB practices possibly decreases employee turnover and absenteeism. Based on the findings, it was recommended that work-life balance options should be fashioned to facilitate employees balancing their work and personal lives. In Tanzania, Mhando \& Kayuni (2019) explored the challenges facing working mothers, both at work and home, and their coping strategies. They found that working mothers face individual, societal, and organizational challenges at work.

In Kenya, Mohamud (2016) investigated the effect of paternity leave on employee productivity, the effect of paternity leave of organization performance and the effect of paternity leave on employee satisfaction. A descriptive research design using Kenya Power, headquarters as the case of the study was utilized. The study found that there was a positive significant correlation between the provision of paternity leave and perception of concern by the company to employees, employee satisfaction and employee commitment. Another study by Muasya (2016) used a total of 375 female teachers from three towns and Nairobi city to examine the informal work-family balance support offered by the supervisors and colleagues, and suggestions to improve it. Findings indicated that teachers asked for permission/assistance from supervisor/colleagues to attend to family emergencies, and they excessively relied on the supervisor for emotional support (empathy) and counseling from co-workers. Some women did not know whether the school could provide work- family balance support and failed to ask for any support, while others did not receive any support.

The discussed studies in the foregoing paragraphs demonstrate how various forms of leave relate with employee satisfaction. It is empirically illustrated that provision of leave is shown to have positive outcome on employee satisfaction. It is however important to note that most studies (Wooden \& Warren, 2008; Hammer \& Palmgren, 2019) have not linked provision of leave to employee performance. Instead, much focus has been directed at employee engagement. But more significant is the fact that studies covering adherence to leave policies and performance of teachers seems scarce or totally neglected. Whereas maternity or paternity leave is important for easing work - social life conflict as demonstrated by various studies (Mohamud, 2016; Hammer \& Palmgren, 2019), the extent to which these have influenced performance of teachers among public secondary schools has not been focused upon. Given the important role played by teachers especially those in secondary schools who handle adolescent learners transiting to tertiary institutions, the need for a relevant study was imperative.

\section{Methods and Materials \\ Research Design}

This study adopted descriptive survey design comprising mixed-methods approach utilizing both quantitative and qualitative methods of data collection and analysis. Mixed-methods approach involves collection and analysis of both 
quantitative and qualitative data (.Akhtar, 2016). Descriptive research is a technique where information is gathered from a sample of people using a questionnaire or interview technique (Sileyew, 2019).

\section{Target Population and Sample Size}

Target population refers to the entire group of individuals or objects that the researcher has chosen to study (Matula et al 2018). The target population of this study was drawn from 257 public secondary schools in Homa Bay County. It comprised a total of 257 principals and 2,231 teachers in Homa Bay County (County Education Office, Homa Bay, 2019).

The study used Krejcie \& Morgan (1970) Table to select 74 public secondary schools out of the 257 according to their categories of National, Extra-County, County and sub-County schools. Stratified proportionate sampling is considered appropriate because the sizes of the samples from different strata are kept proportionate to the size of the strata. Table 1: Sample Distribution.

Table 1 : Sample Size Distribution

\begin{tabular}{|l|c|c|c|c|}
\hline School category & No of schools & Sample Size & No of Principals & No. of teachers \\
\hline National & 2 & 2 & 2 & 4 \\
Extra County & 23 & 5 & 5 & 20 \\
County & 43 & 10 & 10 & 40 \\
Sub County & 189 & 57 & 57 & 228 \\
\hline Total & 257 & 74 & 22 & 292 \\
\hline
\end{tabular}

According to Homa Bay County Education Office (2019) there were 2231 teachers in the county. Four teachers (a $\mathrm{HoD}$, class teacher, subject teacher and a teacher responsible for extra-curricular in schools) were purposively selected from the participating schools. Simple random sampling was used to get the final participants. A total of 292 teachers participated in the study. The sampled number of teachers falls within the recommended range of between $10 \%$ and $30 \%$ of the target population (Yeong et al, 2018; Fuster, 2019).

\section{Data Collection Instruments}

Questionnaire and interview schedule were used for data collection. The study used closed ended questionnaire to collect quantitative data from the teachers. Questionnaire was deemed suitable in this study since it solicited views of respondents on their experiments with the study phenomena: provision of leave by the institution and the Ninistry of education (Creswell \& Plano, 2018). Semi structured interviews were used in the study to collect data from school principals. The interview schedule was appropriate for the study as it provided in-depth information and a detailed understanding of the issue under research.

\section{Validity of Instruments}

Instrument validity was measured by conducting construct and content validity measurements. Construct validity was attained through operationalization of the research variables. The researcher ensured that the operationalization through translation reflects the true meaning of the constructs. According to Ceswell and Plano (2018), construct validity is how the researcher translates or transforms a concept of an idea into function and operating reality. Content validity index (CVI) was used to measure the degree of which the instruments had appropriate items for measuring adherence to leave policies (Dawadi, Shrestha \& Giri, 2021). Four experts were asked to rate each scale item in terms of its relevance to the underlying constructs using a 4-point ordinal scale:1=not relevant; $2=$ somewhat relevant; $3=$ quite relevant; $4=$ highly relevant. Then, for each item, the CVI was computed as the number of experts giving a rating of either 3 or 4 (thus dichotomizing the ordinal scale into relevant and not relevant), divided by the total number of experts. The instrument was rated as highly relevant by three out of four judges, giving a CVI of .80 .

\section{Reliability of Instrument}

Split-half method was done during pilot study with randomly selected 29 respondents to test instrument reliability. Internal consistency of the instrument was determined via split-half reliability index using Cronbach's Alpha coefficient (Cronbach, 1970). Split-half method involved dividing the test scales into two halves of equal items then calculating the coefficients of each half (Haradhan, 2017). The internal consistency (reliability) of the study generated an Alpha coefficient of 0.849 which is greater than the threshold 0.7 espoused by Nunnaly (1978).

\section{Data Analysis and Presentation}


Data collected was processed and analyzed using descriptive statistics: mean (M), Standard Deviation (SD) and regressions with the aid of Statistical Package for the Social Sciences (SPSS) tool. The regression model used is as shown below:

$\mathrm{Y}_{0}=\beta_{0}+\beta_{1} \mathrm{X}_{1+} \beta_{2} \mathrm{X}_{2}+\varepsilon$

Qualitative data obtained from interviews was analysed through Thematic Analysis. This entailed categorization of generated answers into outstanding themes and reported in narrative forms (Clarke \& Braun 2017).

\subsection{Results and Discussions \\ Teacher Performance}

The first part of the study instrument enquired about the extent to which the sampled teachers were undertaking their performance activities based on a 10 point question items. The respondents were asked to rate the items on a scale of 1 - Strongly Disagree, 2 - Disagree, 3 Neutral, 4 - Agree and 5 - Strongly Agree. The results were analyzed and presented in table 2 .

Table 2 : Level of Teacher Performance

\begin{tabular}{|l|l|c|c|c|c|}
\hline SN & \multicolumn{1}{|c|}{ ITEMS } & N & MEAN & $\begin{array}{c}\text { STD } \\
\text { ERROR }\end{array}$ & $\begin{array}{c}\text { STD } \\
\text { DEV }\end{array}$ \\
\hline 1 & I am satisfied with my job & 240 & 4.40 & 0.041 & 0.630 \\
\hline 2 & $\begin{array}{l}\text { I complete the syllabus as per the school } \\
\text { requirement }\end{array}$ & 240 & 4.43 & 0.037 & 0.566 \\
\hline 3 & Students perform as expected in my subject & 240 & 3.35 & 0.064 & 0.986 \\
\hline 4 & $\begin{array}{l}\text { I have no plans of asking for transfer from this } \\
\text { school }\end{array}$ & 240 & 3.24 & 0.080 & 1.237 \\
\hline 5 & $\begin{array}{l}\text { WLB practices help me in improving my time } \\
\text { management skills }\end{array}$ & 240 & 3.75 & 0.059 & 0.916 \\
\hline 6 & $\begin{array}{l}\text { I continue working in this school because it has most } \\
\text { WLB practices }\end{array}$ & 240 & 3.33 & 0.074 & 1.147 \\
\hline
\end{tabular}

Table 4.2 shows that all the 240 respondents reached by the study respondent to the items. Two items 'I am satisfied with my job and I complete the syllabus as per the school requirement' registered highest means of $\mathrm{M}=4.40$ and 4.43 respectively. This means imply that the respondent seemed to strongly agree on the two items. The small standard deviations on the two items ( 0.630 and 0.566 respectively) seems to suggest that the response of all the 240 respondents did not vary so much from the respective mean.

Respondents seems to agree that with current WLB, their performance keep improving ( $M=3.58: \mathrm{SD}=0.845)$; that they were extrinsically motivated to performance $(\mathrm{M}=3.49 \mathrm{SDV}=0.994)$; that WLB practices help them in improving their time management skills $(\mathrm{M}=3.75 \mathrm{STD}=0.916)$

Although respondents seems to agree on most of the items under the teachers performance, there were items that registered higher standard deviation. This items included the issues that respondents had no plans of asking for transfer from this school $(\mathrm{M}=3.24 ; \mathrm{SD}=1.237)$. This seems to show highest variability around the mean which implied that teachers neither agreed nor disagreed that they had no plans of asking for transfer from the school. This implies that although teachers were working hard to improve their performance, there were sections of teachers who were unhappy with the schools they were teaching in and thus could commit themselves and were having plans to ask for transfers

The study further sought to establish the composite mean for all the 6 items on adherence to leave policies. The likert type data was transformed to continuous variable to enable computations of composite mean. The general mean (Composite mean) was interpreted base on the score for 10 items for each respondent. This score ranges between 5 (if the responded rated strongly disagree on the 6 items i.e $1 \times 5$ ) and 30 (if the respondent rated strongly agree on the 6 items ( 5 X 10). The result of analysis were reported in table 3 
Table 3: Composite mean on items under adherence to leave practices

\begin{tabular}{|c|c|c|c|c|c|}
\hline \multirow{2}{*}{$\begin{array}{c}\mathrm{N} \\
\text { Statistic }\end{array}$} & \multirow{2}{*}{$\begin{array}{c}\text { Minim } \\
\text { um } \\
\text { Statisti } \\
\text { c }\end{array}$} & \multirow{2}{*}{$\begin{array}{c}\text { Maximu } \\
\text { m } \\
\text { Statistic }\end{array}$} & \multicolumn{2}{|c|}{ Mean } & \multirow{2}{*}{$\begin{array}{l}\text { Std. Deviation } \\
\text { Statistic }\end{array}$} \\
\hline & & & $\begin{array}{l}\text { Statisti } \\
\text { c }\end{array}$ & Std. Error & \\
\hline 240 & 27 & 30 & 35.74 & 0.321 & 4.970 \\
\hline
\end{tabular}

Table 3 shows that the score of all the 240 respondents varied between 27 which can be interpreted as neutral and 30 which implies very strongly agree on all the 6 items. The mean was recorded as 35.74 with a standard deviation of 4.970. Since the mean is on the higher side of the continuum tending towards 40 , it was concluded that respondents seemed to agree on all the items within this variable

Correlation between adherences to leave practices on teachers' performance

The study sought to establish the relationship between adherences to leave practices on teachers' performance and its significance. This section also tests the first null hypothesis:

\section{$\mathrm{H}_{0}$ : There is no significant relationship between adherences to leave practices on teachers' performance}

Table 4: Correlation between adherences to leave practices and teachers' performance

\begin{tabular}{|l|l|r|c|}
\hline \multicolumn{2}{|l|}{} & \multicolumn{1}{|c|}{$\begin{array}{c}\text { Adherence } \\
\text { to leave } \\
\text { practice }\end{array}$} & Teacher Performance \\
\hline $\begin{array}{l}\text { Adherence to leave } \\
\text { practice }\end{array}$ & $\begin{array}{l}\text { Pearson } \\
\text { Correlation }\end{array}$ & 1 & $.467^{* *}$ \\
\cline { 2 - 4 } & Sig. (2-tailed) & & .000 \\
\cline { 2 - 4 } & $\mathrm{N}$ & 240 & 240 \\
\hline \multirow{3}{*}{ Teacher Performance } & $\begin{array}{l}\text { Pearson } \\
\text { Correlation }\end{array}$ & $.467^{* *}$ & 1 \\
\cline { 2 - 4 } & Sig. (2-tailed) & .000 & 240 \\
\cline { 2 - 4 } & N & 240 & \\
\hline & $* *$ Correlation is significant at the 0.01 level (2-tailed). \\
\hline
\end{tabular}

Table 4 shows a correlation of $r=0.467$ with $p<0.000$. A correlation of $r-0.467$ implies that there is a positive moderate correlation between adherences to leave practices and teachers' performance

Testing of null hypothesis 1

Based on table 4.20, the results on testing the null hypothesis that there is no significant relationship between adherences to leave practices on teachers' performance showed a $P$ value of $p=0.00$ which is less than 0.05 level of significant. This led to rejection of the null hypothesis that there is no significant relationship between adherence to leave practices and teachers' performance. It was therefore concluded that there was a significant positive moderate correlation leave practices and teachers' performance

Regression analysis of adherences to leave practices and teachers' performance

The study sought to determine how adherences to leave practices predicted teachers' performance. A linear regression analysis was therefore computed and based on the following model

$\mathrm{Y}=\mathrm{a}+\beta \mathrm{x}_{1}+\mathrm{e}$

Where

Y - Teachers' performance (Dependent variable)

A - Constant

$\beta$ - change in $Y$

$\mathrm{X}$ - Adherence to leave practices (Independent or Predictor Variable)

Regression analysis were presented in Table 5, table 6 and table 7 as follows

Table 5 : Regression model summary of adherence to leave practices on Teacher performance

\begin{tabular}{l|c|c|c|} 
R & R Square & Adjusted R Square & Std. Error of the Estimate \\
\hline
\end{tabular}


Table 5 shows R Square of 0.218 with an adjusted R square of 0.215 . This implies that adherence to leave practices explains $21.8 \%$ variations in teachers' performance

The study further sought to determine whether the model represented in table 5 was fit and significant. This led to computation of ANOVA analysis as presented in Table 6.

Table 6 : ANOVA table on adherence to leave practices and teachers performance

\begin{tabular}{|l|c|c|c|c|c|}
\hline & Sum of Squares & df & $\begin{array}{c}\text { Mean } \\
\text { Square }\end{array}$ & F & Sig. \\
\hline $\begin{array}{l}\text { Regressio } \\
\mathrm{n}\end{array}$ & 2040.141 & 1 & 2040.141 & 66.488 & $.000^{\mathrm{b}}$ \\
\hline Residual & 7302.855 & 238 & 30.684 & & \\
\hline Total & 9342.996 & 239 & & & \\
\hline
\end{tabular}

Table 6 show statistics to ascertain whether the model which shows adherence to leave practices as a predictor of teachers' performance is fit. The results show $F=66.488$ with $\mathrm{P}$ - Value $=0.00$. Since P- values were found to be less than 0.05 level of significant, it was concluded that model was significant and that adherence to leave practices is a significant predictor of teachers' performance

The study sought to establish how a unit of adherence to leave practices led to increase in teachers' performance. The results of analysis were presented in table 7.

Table 7 : Coefficients table of adherence to leave practices and teachers performance

\begin{tabular}{|c|c|c|c|c|c|c|}
\hline \multirow{2}{*}{\multicolumn{2}{|c|}{ Model }} & \multicolumn{2}{|c|}{$\begin{array}{l}\text { Unstandardized } \\
\text { Coefficients }\end{array}$} & \multirow{2}{*}{$\begin{array}{c}\begin{array}{c}\text { Standardize } \\
\text { d } \\
\text { Coefficients }\end{array} \\
\text { Beta } \\
\end{array}$} & \multirow[t]{2}{*}{$\mathbf{t}$} & \multirow[t]{2}{*}{ Sig. } \\
\hline & & $\mathbf{B}$ & Std. Error & & & \\
\hline \multirow[t]{2}{*}{1} & (Constant) & 15.785 & 2.601 & & 6.068 & .000 \\
\hline & $\begin{array}{l}\text { Adherence to leave } \\
\text { practice }\end{array}$ & .588 & .072 & .467 & 8.154 & .000 \\
\hline
\end{tabular}

Table 7 shows a unit of adherence to leave practice leads to an increase of 0.588 in teachers' performance. Based on P-Value of 0.00 as shown on table 7, this increase was found to be significant since it was less than 0.05 level of significant. If this statistics is substituted in the above mode

$\mathrm{Y}=\mathrm{a}+\beta \mathrm{x}_{1}+\mathrm{e}_{\mathrm{b}}$

Then

$\mathrm{Y}=15.785+0.588(21.8)=28.577$

When the constant is considered in the model, a unit of adherence to leave practice leads to increase in teacher performance by 28.577 units.

Regression analysis of adherences to leave policies and teachers' performance

The results on the regression analysis of adherence to leave practices on teachers' performance indicated that adherence to leave practices predicted teachers' performance by $21.8 \%$. Further analysis showed that a unit of adherence to leave practices by public secondary schools in the study area can lead to an increase of 28.577 and this increase was found to be significant at 0.05 level of significant. It was also established that adherence to leave practices is a significant predictor of teachers' performance

\section{Discussions}

Findings of this study show that adherence to leave policies by the school administration is significant in predicting performance of teachers among secondary schools in the area. However, the contribution that 
provision of leave to teachers in eliciting their performance is low (21.8\%). This tends to imply that adherence to leave policies by various school administrations in the area is not satisfactory to trachers hence triggering minimum effort towards teacher productivity. This findings seem to contradict some earlier studies which had shown that in organizations where various forms of leave are provided, satisfaction and improved performance are realised. For instance, Begall, et al (2020) found that supplemental family leave elicits higher work effort and extra-role behavior in employees in Netherlands. Similarly, Choudhury and Polachek (2019) found that paid parental leave had a stronger impact on families that were below poverty line. However, findings in some studies particularly in Africa found contrary results to the current study. Mhando \& Kayuni (2019) found that working mothers face individual, societal, and organizational challenges at work. Similarly, Muasya (2016) found that Kenyan schools do not provide work friendly atmosphere for lactating mothers who ofter rely on friendly teachers to cope with work-family distress. It can therefore be deduced that leave or time-off policies for employees do not favour all teachers in public secondary schools. More so, female teachers who are breast feeding or who have young families are not favoured in the prevailing work - life policy provisions.

\section{Conclusions}

The study concludes that employee leave policies as administered in public secondary schools have had minimal influence on performance of teachers. It is also concluded that the policies do not consider teachers with young families who need close attention, especially lactating teachers.

\section{Acknowledgement}

The author is grateful to all the teachers and principals who participated in this study. All the public secondary schools in Homa Bay County were so important to this study for the information they provided. This enabled the researcher to come up with this work successfully.

\section{Reference}

1. Akhtar, I. (2016). Research design. Research in Social Science: Interdisciplinary Perspectives, Available at: https://www.researchgate.net/publication/308915548

2. Al Kabir, A. and Tirno, R.R. (2018). Impact of Work-Life Balance on Employees' Turnover and Turnover Intentions: An Empirical Study on Multinational Corporations in Bangladesh. Jahangirnagar University Journal of Management Research, 115 - 33.

3. Begall, K., van Breeschoten, L., van der Lippe, T. \& Poortman, A-R. (2020). Supplemental family leave provision and employee performance: Disentangling availability and use. The International Journal of Human Resource Management, DOI: 10.1080/09585192.2020.1737176.

4. Choudhury, A.R. and Polachek, S.W. (2019). The Impact of Paid Family Leave on the Timing of Infant Vaccinations. IZA DP No. 12483. Auburn University at Montgomery.

5. County Education Office of Homa Bay (2019). Teacher enrolment and Recruitment reports. Government of Kenya, Nairobi.

6. Creswell, J. W., \& Plano C. V. L. (2018). Designing and Conducting Mixed Methods Research (3rd ed.). Sage Publications.

7. Dawadi, S., Shrestha, S., \& Giri, R. A. (2021). Mixed-Methods Research: A discussion on its types, challenges, and criticisms. Journal of Practical Studies in Education, 2(2), 25-36 DOI: https://doi.org/10.46809/jpse.v2i2.20

8. Fapohunda, T. (2014). An exploration of the effects of work life balance on productivity. Journal of $\quad$ Human Resources Management and Labor Studies, 2 (2), 71-89.

9. Garg, S. and Agrawal, P. (2020). Family-friendly practices in the organization: A citation analysis. International Journal of Sociology and Social Policy: DOI 10.1108/IJSSP-12-2019-0251.

10. Hammer, P. and Palmgren, R. (2019). How parental leave policies influence employee engagement. Thesis report submitted to University of Gavil.

11. Haradhan, M. (2017). Two Criteria for Good Measurements in Research: Validity and Reliability. Annals of Spiru Haret University, 17(3), 58-82

12. Hendrawijaya, A. T., Hilmi, M. I., Hasan, F., Imsiyah, N., \& Indrianti, D. T. (2020).Determinants of Teacher Performance with Job Satisfactions Mediation. International Journal of Instruction, 13(3), 845-860. 
13. International Labour Organization (ILO, 2018). Decent Work and the Sustainable Development Goals: A Guidebook on SDG Labour Market Indicators, Department of Statistics (STATISTICS), Geneva.

14. Koutouzis, M. \& Malliara, K. (2017). Teachers' job satisfaction: The effect of principal's leadership and decision- making style. International Journal of Education, 9 (4), 71 - 90.

15. KPMG (2017). Sustainable development goals (SDGs): leveraging CSR to achieve SDGs. available at: http.www.assets.kpmg i dam i kpmg i pdf i 2017/12 i SDG_New_Final_Web

16. Matula, P. D., D. N. Kyalo, A. S. Mulwa, and L. W. Gichuhi. (2018). Academic Research Proposal Writing: Principles, Concepts and Structures. Nairobi: Acts Press,

17. Mhando, N.E. \& Kayuni, R. (2019). Challenges and coping strategies of employed mothers in a social security scheme in Tanzania. Tanzania Journal of Development Studies, 17, (2), 96-114.

18. Mohamud, M.E. (2016). The effect of paternity leave on employee productivity: A case of Kenya Power. $\quad$ Unpublished thesis submitted to USIUA.

19. Muasya, G. (2016). Is work-family balance a possibility? The case of Kenyan female teachers in urban public schools. International journal of educational administration and policy studies, 8 (5), $37-47$.

20. Nwagbara, U. (2020). Institutions and organisational work-life balance (WLB) policies and practices: Exploring the challenges faced by Nigerian female workers. Journal of Work- Applied Management, 12 (1), 42-54.

21. Organization of European Cooperation in Development (OECD, 2017). Family database. http://www.oecd.org/els/soc/PF2 1 Parental leave systems.pdf

22. Ostoj, I. (2019). Varying paid annual leave length in the world's economics and its underlying causes. Ekonomicko-manazerske spektrum, 13(1), 62-71.

23. Ryder, G. (2014). The International Labour Organization: The next 100 years1. Journal of Industrial Relations, 57 (5), 748-757.

24. Sileyew, K. J. (2019). Research Design and Methodology : in Intech Open, on August 7. DOI: 10.5772/intechopen.85731. Available online also at: https://www.intechopen.com/onlinefirst/ research-design-and-methodology

25. UNICEF (2017). Setting the pace in education. Geneva: UNICEF

26. United Nations. (2015). The Sustainable Development Goals Report, United Nations, New York.

27. Uzun, T. and Özdem, G. (2017). The mediating role of job satisfaction on the relationship between teachers' perceptions of supervisor support and job performances. International journal of educational administration and policy studies, 9(7), 84-90: DOI: 10.5897/IJEAPS2017.0519

28. Wilson, D.M., Punjani, S., Song, Q. and Low, G. (2019). A Study to Understand the Impact of Bereavement Grief on the Workplace. OMEGA — Journal of Death and Dying, O(0) 1-11.

29. World Education Forum (WEF, 2015). The Incheon Declaration. Education 2030, towards inclusive equitable quality education and life long learning. UNDP and UNICEF 